\title{
Atypical femoral fracture following zoledronic acid treatment
}

\author{
Zoledronik asit tedavisi sonrası atipik femoral kırık
}

\author{
Baybars Ataoğlu, MD., Ahmet Yiğit Kaptan, MD., Toygun Kağan Eren, MD., \\ Ali Ekber Yapar, MD., Ahmet Fırat Berkay, MD. \\ Department of Orthopedics and Traumatology, Medical Faculty of Gazi University, Ankara, Turkey
}

\begin{abstract}
A 68-year-old female patient admitted to our clinic with right anterior thigh pain ongoing for six months and which increased in last two months. The patient had no trauma history. The patient had been followed-up for 15 years because of osteoporosis and administrated alendronate and ibandronate treatment for 10 years. Patient had three shots of zoledronate once a year during the last three years. Her pain was increasing when she was walking. Physical examination revealed pain in her right thigh. Radiogram showed thickened lateral cortex of the subtrochanteric area. Magnetic resonance imaging also showed thickening and edema of the same area. These images were correlated with atypical fracture in right femoral subthrochanteric zone. Dual energy X-ray absorptiometry revealed that $\mathrm{T}$ score was -3.3 in lumbar region and -2.5 in femoral neck. Zoledronate treatment was ended. Prophylactic surgical fixation was performed with titanium elastic nails.
\end{abstract}

Keywords: Atypical fracture; titanium elastic nail; zoledronic acid.

Osteoporosis is an important health issue which is characterized with decreasing bone strength. ${ }^{[1]}$ Osteoporotic fractures cause pain, impairment of function, and economic loss. ${ }^{[2]}$ Approximately one of every four males and one of every two females experience fracture related to osteoporosis. ${ }^{[3]}$ Health expenses are inevitable unless proper attempts are started to avoid and treat osteoporosis in early period. ${ }^{[4]}$

Bisphosphonates are the drugs of choice in osteoporosis treatment. They decrease the fracture incidence of vertebra and hip by decreasing bone resorption and increasing bone mineral density. ${ }^{[5]}$
$\ddot{O Z Z}$

Altmış sekiz yaşında bir kadın hasta altı aydır devam eden ve son iki aydır artan sağ ön uyluk ağrısı ile kliniğimize başvurdu. Hastanın travma öyküsü yoktu. Hasta 15 yıldır osteoporoz nedeniyle takip ediliyor, kendisine 10 yıldir alendronat ve ibandronat tedavisi uygulanıyordu. Hastaya son üç yılda, yılda bir kez zolendronat enjeksiyonu yapılmıştı. Ağrısı yürürken artmaktaydı. Fiziksel muayenede sağ uyluğunda ağrı olduğu tespit edildi. Radyogramda subtrokanterik bölgede lateral kortekste kalınlaşma olduğu görüldü. Manyetik rezonans görüntülemede de aynı bölgede kalınlaşma ve ödem olduğu görüldü. Bu görüntüler sağ femoral subtrokanterik bölgede atipik kırık ile ilişkiliydi. Çift enerjili $\mathrm{X}$-1şı absorbsiyometri $\mathrm{T}$ skorunun lumbar bölgede -3.3 , femur boynunda -2.5 olduğunu ortaya koydu. Zolendronat tedavisine son verildi. Titanyum elastik çiviler ile profilaktik cerrahi tespit uygulandı.

Anahtar sözcükler: Atipik kırık; titanyum elastik çivi; zoledronik asit.

Recently, cases who had atypical fracture related to long-term bisphosphonate usage have been reported..$^{[6-9]}$ This is considered as adynamic and fragile bone formation which is related to long-term bisphosphonate usage.

High dose intravenous bisphosphonates have been used in cancer cases who suffered bone metastasis more than postmenopausal osteoporosis. ${ }^{[10]}$ In the cases who suffer bone damage, American Society of Clinical Oncology suggested $4 \mathrm{mg}$ zoledronate intravenous administration every three to four weeks. ${ }^{[10]}$ In postmenopausal osteoporosis, intravenous administration is suggested once a year. ${ }^{[11]}$ Recently,

\footnotetext{
- Received: December 23, 2015 Accepted: January 04, 2016
}

- Correspondence: Baybars Ataoğlu, MD. Gazi Üniversitesi Tıp Fakültesi Ortopedi ve Travmatoloji Anabilim Dalı, 06500 Beşevler, Ankara, Turkey. Tel: +90 312 - 2025528 Fax: +90 312 - 2129008 e-mail: baybarsataoglu@ hotmail.com 


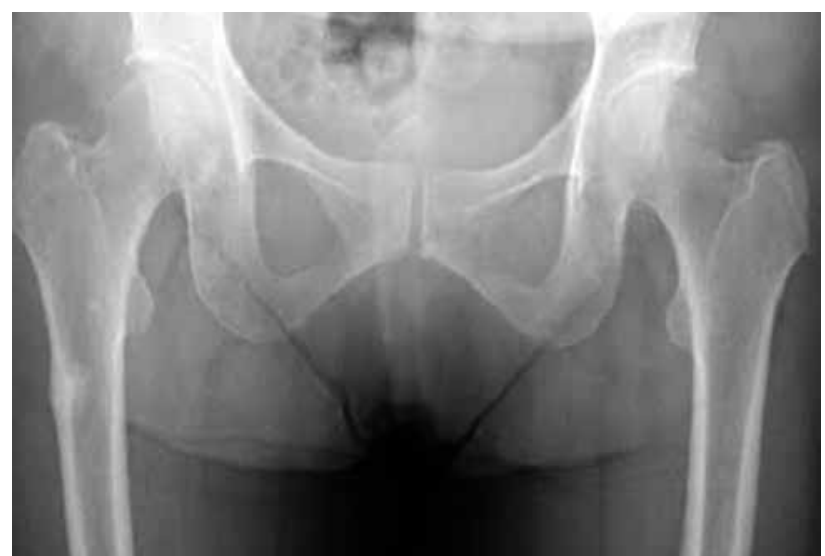

Figure 1. Anteroposterior radiogram showing thickened lateral cortex of subtrochanteric area.

atypical femoral fractures related to zoledronate usage were reported in patients who suffer prostate and breast cancer. ${ }^{[12,13]}$

In this article, we report a female patient who had zoledronate treatment for three years, admitted to our clinic with right thigh pain, was diagnosed with atypical femoral fracture, and treated.

\section{CASE REPORT}

A 68-year-old female patient admitted to our clinic with right anterior thigh pain ongoing for six months and that increased in the last two months. The patient had no trauma history. She had been followed-up for 15 years because of osteoporosis and administrated alendronate and ibandronate treatment for 10 years. She had three shots of zoledronate once a year during the last three years. Her pain was increasing when she was walking.
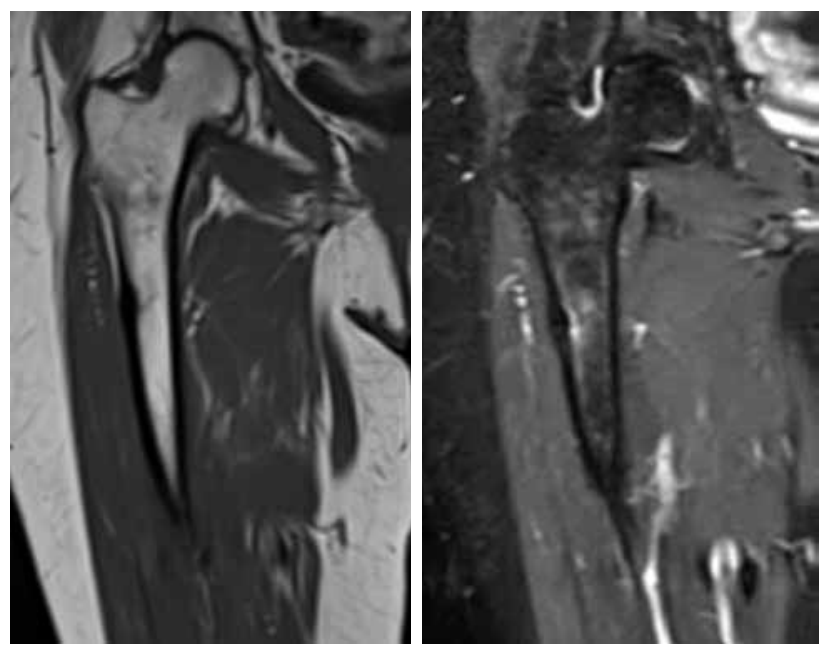

Figure 2. Magnetic resonance imaging also showing thickening and edema of same area.
Physical examination revealed pain in her right thigh. Radiogram showed thickened lateral cortex of the subtrochanteric area (Figure 1). Magnetic resonance imaging (MRI) also showed thickening and edema of the same area (Figure 2). These images were correlated with atypical fracture in right femoral subtrochanteric zone. Dual energy $\mathrm{X}$-ray absorptiometry revealed that the $\mathrm{T}$ score was -3.3 in lumbar region and -2.5 in femoral neck. For management, zoledronate treatment was ended and prophylactic surgical fixation with titanium elastic nails was performed (Figure 3). A written informed consent was obtained from the patient.

\section{DISCUSSION}

Bisphosphonates are the initial therapy to reduce the risk of vertebrae, hip and non vertebral fractures which are related to osteoporosis and their effects have been proved. ${ }^{[14]}$ They are used in Paget's disease, malignancies with bone metastasis, multiple myeloma, and hypercalcemia which are related to malignancies. Bisphosphonates prevent osteoclastic activity and trigger osteoclast apoptosis by engaging to inorganic compounds of the bone. ${ }^{[15,16]}$

The cause of atypical fractures related to long-term bisphosphonate usage is still unknown; yet, there are some mechanisms which are asserted. Most agreed one as a cause of fracture is reduced bone turnover and mechanism of bone repair by suppressing of osteoclasts and osteoblasts. ${ }^{[17,18]}$

American Society for Bone and Mineral Research suggested various criteria to help diagnosing atypical femoral fractures. ${ }^{[17]}$ These fractures occur in the proximal femoral diaphysis or subtrochanteric area. There is thickening at the lateral cortex but transverse or short oblique fracture line can be seen and medial with a "spike" if the fracture extends to the medial cortex. This view at the
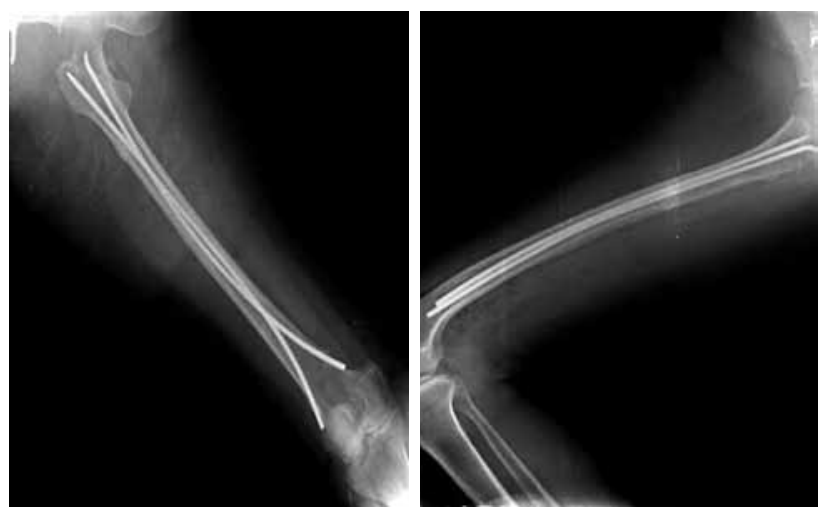

Figure 3. Anteroposterior and lateral radiograms showing prophylactic internal fixation with titanium elastic nails. 
plain radiographs helps us to distinguish atypical femur fracture from stress fracture because the fracture begins from the medial cortex in the stress fracture. When atypical femur fracture is hard to be recognized at plain radiographs, MRI and scintigraphy might help for diagnosis. Magnetic resonance imaging view is characterized with edema at the fracture line, decreased signal on $\mathrm{T}_{1}$ sections and increased signal on $\mathrm{T}_{2}$ sections. Scintigraphy may help to establish a diagnosis by showing thickened lateral cortex and increased radiopharmaceutical uptake at the fracture line. In our patient, there was thickening at the femoral subtrochanteric lateral cortex in plain radiography, and edema at the same area in MRI.

It has been reported that long-term use of bisphosphonate therapy may induce atypical femur fractures. ${ }^{[17]}$ Dell et al. ${ }^{[18]}$ concluded that the incidence of atypical fractures of the femur increases with longer duration of bisphosphonate use. This finding may be partially explained by the pharmacokinetics of bisphosphonates. A single dose of zoledronate has been shown to have sustained anti-resorptive effects at three years. ${ }^{[19]}$

Banffy et al. ${ }^{[20]}$ suggested that nonoperative treatment of bisphosphonate-related femoral stress fractures is not a reliable way to treat these fractures as the majority progress to fracture completion. Prophylactic fixation of femoral stress fractures also reduces total hospital admission time. In another study with 14 atypical femoral fractures in 11 patients, five femoral fractures required surgery because of displacement in 10 months, and the other five patients did not show any improvement in pain and underwent surgery. ${ }^{[21]}$

Atypical femoral fractures may be managed with plate fixation or intramedullary nailing surgery. Intramedullary nailing may be technically difficult due to increased cortical thickening and fragility in long-term bisphosphanate use. ${ }^{[8]}$ However, after intramedullary nailing, bone healing occurs with callus formation and enchondral ossification and bisphosphanates do not affect this phase of bone healing. ${ }^{[22]}$ Bisphosphanates may affect intramembranous ossification phase plate and cause fixation insufficiency. Prophylactic fixation was suggested for possible fracture of contralateral femur in a patient with atypical femoral fracture. ${ }^{[8]}$

We preferred titanium elastic nail fixation for our patient to avoid possible complications of intramedullary nailing and achieve bone healing with endochondral healing.

\section{Declaration of conflicting interests}

The authors declared no conflicts of interest with respect to the authorship and/or publication of this article.

\section{Funding}

The authors received no financial support for the research and/or authorship of this article.

\section{REFERENCES}

1. Atik OS, Uslu MM, Eksioglu F, Satana T. Etiology of senile osteoporosis: a hypothesis. Clin Orthop Relat Res 2006;443:25-7.

2. Atik OS, Gunal I, Korkusuz F. Burden of osteoporosis. Clin Orthop Relat Res 2006;443:19-24.

3. Nieves JW, Cosman F. Atypical subtrochanteric and femoral shaft fractures and possible association with bisphosphonates. Curr Osteoporos Rep 2010;8:34-9.

4. Ataoğlu MB, Atik OŞ, Gül O, Sarıkaya B, Görmeli G, Öztürk BY, et al. A comparison of the measurements with biochemical markers of bone turnover and bone mineral density in the assessment of the efficiency of osteoporosis treatment. [Article in Turkish] Eklem Hastalik Cerrahisi 2013;24:82-6.

5. Somford MP, Draijer FW, Thomassen BJ, Chavassieux PM, Boivin G, Papapoulos SE. Bilateral fractures of the femur diaphysis in a patient with rheumatoid arthritis on longterm treatment with alendronate: clues to the mechanism of increased bone fragility. J Bone Miner Res 2009;24:1736-40.

6. Ayanaoğlu T, Atik OŞ, Tokgöz N, Uçar M. Sacral and pubic insufficiency fractures due to bisphosphonate treatment. Eklem Hastalik Cerrahisi 2015;26:120-4.

7. Odvina CV, Zerwekh JE, Rao DS, Maalouf N, Gottschalk FA, Pak CY. Severely suppressed bone turnover: a potential complication of alendronate therapy. J Clin Endocrinol Metab 2005;90:1294-301.

8. Atik OS, Suluova F, Görmeli G, Yildirim A, Ali AKh. Insufficiency femoral fractures in patients undergoing prolonged alendronate therapy. Eklem Hastalik Cerrahisi 2010;21:56-9.

9. Kwek EB, Goh SK, Koh JS, Png MA, Howe TS. An emerging pattern of subtrochanteric stress fractures: a long-term complication of alendronate therapy? Injury 2008;39:224-31.

10. Hillner BE, Ingle JN, Chlebowski RT, Gralow J, Yee GC, Janjan NA, et al. American Society of Clinical Oncology 2003 update on the role of bisphosphonates and bone health issues in women with breast cancer. J Clin Oncol 2003;21:4042-57.

11. Kanis JA, Burlet N, Cooper C, Delmas PD, Reginster JY, Borgstrom $F$, et al. European guidance for the diagnosis and management of osteoporosis in postmenopausal women. Osteoporos Int 2008;19:399-428.

12. Reddy SV, Gupta SK. Atypical femoral shaft fracture in a patient with non-metastatic prostate cancer on zoledronic acid therapy: effect of therapy or coincidence? Singapore Med J 2012;53:52-4.

13. Kim YS, Park WC. Atypical subtrochanteric femur fracture in patient with metastatic breast cancer treated with zoledronic Acid. J Breast Cancer 2012;15:261-4.

14. McClung M, Harris ST, Miller PD, Bauer DC, Davison KS, Dian L, et al. Bisphosphonate therapy for osteoporosis: benefits, risks, and drug holiday. Am J Med 2013;126:13-20. 
15. Roelofs AJ, Thompson K, Gordon S, Rogers MJ. Molecular mechanisms of action of bisphosphonates: current status. Clin Cancer Res 2006;12:6222-30.

16. Xu XL, Gou WL, Wang AY, Wang Y, Guo QY, Lu Q, et al. Basic research and clinical applications of bisphosphonates in bone disease: what have we learned over the last 40 years? J Transl Med 2013;11:303.

17. Shane E, Burr D, Ebeling PR, Abrahamsen B, Adler RA, Brown TD, et al. Atypical subtrochanteric and diaphyseal femoral fractures: report of a task force of the American Society for Bone and Mineral Research. J Bone Miner Res 2010;25:2267-94.

18. Dell RM, Adams AL, Greene DF, Funahashi TT, Silverman SL, Eisemon EO, et al. Incidence of atypical nontraumatic diaphyseal fractures of the femur. J Bone Miner Res 2012;27:2544-50.
19. Grey A, Bolland M, Wattie D, Horne A, Gamble G, Reid IR. Prolonged antiresorptive activity of zoledronate: a randomized, controlled trial. J Bone Miner Res 2010;25:2251-5.

20. Banffy MB, Vrahas MS, Ready JE, Abraham JA. Nonoperative versus prophylactic treatment of bisphosphonateassociated femoral stress fractures. Clin Orthop Relat Res 2011;469:2028-34.

21. Ha YC, Cho MR, Park KH, Kim SY, Koo KH. Is surgery necessary for femoral insufficiency fractures after longterm bisphosphonate therapy?Clin Orthop Relat Res 2010;468:3393-8.

22. Atik OS, Oztürk AM, Kunat C, Cetinkaya M, Kaptan Y. Do atypical femoral fractures in patients with prolonged alendronate treatment heal? Eklem Hastalik Cerrahisi 2014;25:52-5 